\title{
IMPLEMENTASI PENDEKATAN SAINTIFIK KURIKULUM 2013 PADA PEMBELAJARAN IPA DI SD/MI KELAS IV
}

\author{
Suparlan \\ Dosen STIT PALAPA NUSANTARA LOTIM NTB \\ maniahparlan66@gmail.com
}

\begin{abstract}
ION
Elementary school (SD) Of Muhammadiyah Demengan Yogyakarta is featured SD. It is seen from the miraculous achievements of students both at provincial and national levels, adequate infrastructure, a spirit of community to send their children in elementary school. Accordingly, of course, can not be separated from the role of teachers as educators and counselors to provide services in the classroom and outside the classroom. Muhammadiyah elementary schools including one school are designated by the ministry of religion (MORA) to implement the curriculum by 2013. Therefore it is necessary to do research on the implementation of the scientific approach in science (IPA) learning curriculum in 2013.
\end{abstract}

Type of research is qualitative lookups. As for the subject of this research is that teachers and students in the fourth grade (IV) of Muhammadiyah elementary school Demengan Yogyakarta. data collection by interview, documentation and observation. the process of data analysis, namely: examining the data, data reduction, and data presentation.

he results of this research : (1) teachers in SD Muhammadiyah already understand and know the theory of scientific approach, steps in learning. As for the understanding of the scientific approach according to the fourth grade (IV) of Muhammadiyah elementary school teachers, Mr Kastowo "approach that starts from the observation first, continue to question, then the experiment, then summed and later would know that better results". (2) scientific approach in SD Muhammadiyah Yogyakarta new Demengan already implemented, but not perfect, because in their implementation more teachers using students' understanding and not exposed to the medium of learning. (3) As for the obstacles faced by teachers in the application of scientific approaches, namely, first a very short time per sub-theme. Both enormous costs required to confront instructional media. Third when teachers find students who are less active during learning.

Key words: Scientific, Curriculum 2013 And Science (IPA). 


\begin{abstract}
ABSTRAK
Sekolah Dasar (SD) Muhammadiyah Demangan Yogyakarta merupakan SD unggulan. Hal itu di lihat dari beberapa prestasi siswa baik di tingkat Provinsi maupun Nasional, sarana dan prasarana yang memadai, suatu semangat masyarakat untuk menyekolahkan anaknya di SD tersebut. Hal demikian, tentunya tidak bisa terlepas dari peran guru selaku pendidik dan pembimbing dalam memberikan layanan di dalam kelas maupun di luar kelas. Sekolah Dasar Muhammadiyah termasuk salah satu sekolah yang di tunjuk oleh Kemenag untuk menerapkan kurikulum 2013. Perlu dilakukan penelitian tentang implementasi pendekatan saintifik kurikulum 2013 pada pembelajaran IPA.
\end{abstract}

Jenis penelitian yang dilakukan adalah metode kualitatif. Menjadi subjek dalam penelitian ini guru dan siswa di kelas IV SD Muhammadiyah Demangan Yogyakarta. Pengumpulan data dengan wawancara, dokumentasi, dan observasi. Proses analisis data yaitu: menelaah data, reduksi data, dan penyajian data.

Hasil penelitian ini: (1). Guru di SD Muhammadiyah sudah memahami dan mengerti teori pendekatan saintifik, langkah-langkah dalam pembelajaran. Pendekatan saintifik menurut guru kelas IV SD Muhammadiyah, Pak Kastowo "pendekatan yang dimulai dari pengamatan dulu, terus pertanyaan, kemudian percobaan, kemudian menyimpulkan dan nanti akan tahu hasilnya itu lebih baik". (2) Pendekatan saintifik di SD Muhammadiyah Demangan Baru Yogyakarta sudah di implementasikan, tetapi belum sempurna, sebab dalam implementasinya guru lebih menggunakan pemahaman siswa dan tidak dihadapkan pada media pembelajaran. (3) Adapun kendala yang dihadapi guru pada penerapkan pendekatan saintifik yaitu, pertama waktu yang sangat singkat per sub tema. Kedua biaya yang dibutuhkan sangat besar untuk menghadapkan media pembelajaran. Ketiga ketika guru menemukan siswa yang kurang aktif saat pembelajaran.

Kata Kunci: saintifik, kurikulum 2013 dan IPA.

\title{
Latar Belakang.
}

Pendidikan sedang mengalami berbagai perubahan yang cukup mendasar, terutama berkaitan dengan Undang-Undang Sistim Pendidikan Nasional (UU SISDIKNAS), manajemen, dan kurikulum, yang diikuti oleh perubahan-perubahan teknis lainya. Perubahan-perubahan tersebut diharapkan dapat memecahkan berbagai permasalahan pendidikan. Baik masalah konvensional maupun masalahmaslah yang muncul bersamaan dengan hadirnya ide-ide baru (masalah inovatif). Di samping itu, melalui perubahan tersebut diharapkan terciptanya iklim yang kondusif bagi pengkatan kualitas pendidikan, dan Pengembangan Sumber Daya 
Manusia (PSDM), untuk mempersiapkan bangsa Indonesia memasuki era kesejagatan dalam kesemerautan global. ${ }^{1}$

Pembangunan nasional di bidang pendidikan merupakan bagian dari upaya mencerdaskan kehidupan bangsa dan meningkatkan kualitas manusia Indonesia dalam mewujudkan masyarakat yang damai, demokratis, berkeadilan, berdaya saing, maju dan sejahtera yang didukung oleh manusia Indonesia yang sehat, mandiri, beriman, bertaqwa, berakhlak mulia, cinta tanah air, berkesadaran hukum dan lingkungan, menguasai ilmu pengetahuan dan teknologi, serta memiliki etos yang tinggi dan berdisiplin dalam wadah Negara kesatuan Republi Indonesia..

Untuk mewujdukan visi pendidikan nasional tersebut diperlukan peningkatan dan penyempurnaan dan penyelenggaraan pendidikan nasional, yang sesuai dengan kebutuhan dan perkembangan masyarakat, serta perkembangan masyarakat, serta perkembangan ilmu pengetahuan dan teknologi serta kesenian. Dalam kerangka ini pula diberlakukanya undang-undang system Pendidikan Nasional pada tahun 2003, dan peraturan pemerintah No. 19 tahun 2005 tentang Standar Nasional Pendidikan (SNP), yang telah dilakukan penataan kembali pada Peraturan Pemerintah No. 32 tahun 2013. ${ }^{2}$

Adagium "ganti mentri ganti kurikulum" tidak dapat terelakkan lagi dalam proses pengembangan kurikulum 2013 ini. Justifikasi akademiknya adalah di mana pun di dunia ini, kurikulum selalu mengalami penyesuaian dengan perkembangan masyarakat. Maka perubahan kurikulum bukan suatu yang haram, melainkan itu sebagai kebutuhan masyarakat. Justifikasi akademik lainya adalah atas perubahan kurikulum ini adalah melihat tantangan ke depan yang lebih keras lagi, baik untuk masalah lingkungan hidup, kemajuan teknologi informasi, globalisasi ekonomi, serta kebangkitan industry kreatif dan budaya. Kesemuanya itu membutuhkan kemampuan (komptensi) dalam berkomunikasi, berfikir jernih dan kritis, mempertimbangkan segi moral dalam menghadapi suatu permasalahan, serta toleran terhadap pandangan yang berbeda, dan memiliki minat luas dalam kehidupan, maupun memiliki kesiapan untuk bekerja dalam suatu tim. ${ }^{3}$

Pengembangan kurikulum 2013 ini melanjutkan pengembangan Kurikulum Berbasis Komptensi (KBK) yang telah dirintis pada tahun 2014 dengan mencakup komptensi sikap, pengetahuan, dan keterampilan. Kurikulum 2013 dirumuskan dan dikembangkan dengan suatu optimis yang tinggi untuk menghasilkan lulusan sekolah yang lebih cerdas, kreatif, inovatif, memiliki kepercayaan diri yang tinggi sebagai individu maupun sebagai bangsa, serta toleran terhadap segala perbedaan

${ }^{1}$ E. Mulyasa, Menjadi Kepala Sekolah Professional Dalam Konteks Penyuksesan MBS Dan KBK (Bandung: Remaja Rosdakarya, 2005), Hlm.V.

2 E. Mulyasa, Pengembangan Dan Implementasi Kurikulum 2013, (Bandung: Remaja Rosdakarya, 2013), Hlm.4.

${ }^{3}$ Darmaningtiyas, Makalah Dalam Seminar Pendidikan Dengan Tema "Kurikulum 2013: Persepektif Ideology, Filosofi, Dan Politik Pendidikan Nasional” Yang Diselenggarakan Oleh DEMAF Ilmu Tarbiyah Dan Keguruan UIN Sunan Kalijaga, Di Gedung Convention Hall Lantai Dasar, Pada Hari Senin Tanggal 12 Mei 2014 Pukul 08:00 Sampai Jam 11: 30. Hlm.3. 
yang ada. Semua itu dimaksudkan untuk mencapai tujuan pendidikan nasional seperti yang diamanatkan dalam UU No. 20 tahun 2013 tentang system pendidikan nasional, yaitu "berkembangnya potensi peserta didik agar menjadi manusia yang beriman dan bertaqwa kepada Tuhan Yang Maha Esa, berakhlak mulia, sehat, berilmu, cakap, kreatif, mandiri, dan menjadi warga Negara yang demokratis serta bertanggung jawab". ${ }^{4}$

Tujuan pengembangan kurikulum 2013 seperti yang dirumuskan dalam konsepnya, terutama adalah untuk mengatasi masalah dan tantangan berupa kompetensi riil yang dirumuskan oleh dunia kerja, globalisasi ekonomi pasar bebas, membangun kualitas manusia Indonesia yang berakhlak mulia, dan menjadi warga Negara yang bertanggung jawab. Pada hakikatnya pengembangan kurikulum 2013 adalah upaya yang dilakukan melalui salah satu elemen pendidikan, yaitu kurikulum untuk memperbaiki kualitas hidup dan kondisi sosial bangsa Indonesia secara lebih luas. Jadi, pengembangan kurikulum 2013 tidak hanya berkaitan dengan persoalan kualitas pendidikan saja, melainkan kualitas kehidupan bangsa Indonesia secara umum. ${ }^{5}$

Kurikulum 2013 sudah banyak sekolah yang melakukan uji coba, baik dari tingkat SD/MI sampai tingkat SMA, karna di tahun ini masih uji kelayakan 2013 maka sangat menarik sekali untuk lihat seperti apa penerapaya dan perkembanganya. Untuk itu sangat menarik untuk diteliti sehingga saya kemas dalam bentuk judul yaitu "Implementasi Kurikulum 2013 Dalam Pembelajaran IPA Dengan Scientific Approc di MI".

\section{Metode Penelitian}

Untuk melakukan penelitian ini, peulis membuat batasan dalam menentukan rumusan masalah. Addapun batasan yang di maksund adalah : (1) Bagaimana persepsi guru tentang pendekatan saintifik pada Kurikulum 2013 dalam Pembelajaran IPA di SD Muhammadiyah Demangan Yogyakarta? (2) Bagaimana pelaksanaan pendekatan saintifik dalam Pembelajaran IPA di SD Muhammadiyah Demangan Yogyakarta? (3) Kendala-kendala apa saja yang dihadapi guru dalam Penerapan Pendekatan saintifikdi SD Muhammadiyah Demangan Yogyakarta?

Sedangkan tujuan dan kegunaan penelitian ini adalah (1) Mengetahui persepi guru dalam pembelajaran IPA dengan pendekatan saintifik. (2) Mengetahui implementasi pendekatan saintifik kurikulum 2013 di SD Muhammadiyah Demangan Baru Yogyakarta dalam pembelajaran IPA. (3) Mengetahui kendala pada saja yang dihadapi oleh guru pada implementasi pendekatan saintifik dalam pembelajaran IPA.

\footnotetext{
${ }^{4}$ Ibid.,hlm.3.

${ }^{5}$ Ibid.,hlm.3.
} 
Jenis penelitian ini menggunakan metode penelitian kualitatif yaitu penelitian yang bermaksud memahami fenomena tentang apa yang dialami oleh subjek penelitian. ${ }^{6}$ Adapun yang menjadi subjek dalam penelitian ini yaitu guru dan siswa kelas IV A, sedangkan yang menjadi objeknya SD Muhammadiyah Demangan Baru Yogyakarta.

\section{Pembahasan}

1. Kurikulum 2013.

Istilah kurikulum muncul pertama kali dan digunakan dalam bidang olah raga. Secara etimologis curiculum yang berasal dari bahasa yunani yaitu curir yang artinya "pelari" dan urere yang berarti "tempat berpacu". Jadi istilah kurikulum pada zaman Romawi kuno mengandung pengertian sebagai suatu jarak yang harus ditempuh oleh pelari oleh pelari dari garis start sampai garis finish. ${ }^{7}$ Dalam bahasa Prancis istilah kurikulum berasal dari kata courier yang berarti berlari (to run). Kurikulum berarti yang harus ditempuh oleh seorang pelari dari garis start sampai dengan garis finish untuk memperoleh medali atau penghargaan. ${ }^{8}$

Kurikulum adalah seperangkat rencana dan pengaturan mengenai tujuan, isi, dan bahan pelajaran serta cara yang digunakan sebagai pedoman penyelenggaraan kegiatan pembelajaran untuk mencapai tujuan pendidikan tertentu. Tujuan tertentu ini meliputi tujuan pendidikan nasional serta kesesuaian dengan kekhasan, kondisi, potensi daerah, satuan pendidikan, dan peserta didik. Oleh sebab itu kurikulum disusun oleh satuan pendidikan untuk memungkinkan penyesuaian program pendidikan dengan kebutuhan dan potensi yang ada di daerah. . ${ }^{9}$

Disini kami ungkapkan beberapa definisi menurut para pakar kurikulum. (a) Saylor, Alexander, dan Lewi (1974) mendepinisikan kurikulum merupakan segala upaya sekolah untuk mempengaruhi siswa agar dapat belajar, baik dalam ruangan kelas maupun diluar sekolah. (b) Harold B. Alberty (1956) memandang kurikulum sebagai semua kegiatan yang diberikan kepada siswa dibawah tanggung jawab sekolah. ${ }^{10}$ (c) Daniel Tanner dan Laurel Tanner (1975) menyatakan bahwa kurikulum adalah perencanaan yang berisi tentang petunjuk belajar serta hasil yang diharapkan ${ }^{11}$ (d) Carter V. Good dalam

${ }^{6}$ Sugiyono, Metode Penelitian Kuantitatif, Kualitatif dan $R \& D$, (Bandung: Alfabeta, 2013),hlm. 213. 2013),hlm.19

${ }^{7}$ Sholehah Hidayat,Pengembangan Kurikulum Baru, (Bandung: PT Remaja Rosdakarya,

${ }^{8}$ Zainal Arufin, Konsep Dan Model Pengembangan Kurikulum, (Bandung: PT Remaja Rosdakarya,2011),hlm.2

${ }^{9}$ Sri Minarti, Manajemen Sekolah, (Yogyakarta: AR-RUZZ MEDIA, 2011). Hlm. 103.

${ }^{10}$ Rusman, Manajemen Kurikulum,(Jakarta:PT RajaGrapindo Persada,2009),hlm.3

${ }^{11}$ Wina Sanjaya,Kurikulum Dan Pembelajaran,(Jakarta: Prenada Media Group:2010),hlm.8 
Dictionary Of Education, menyebutkan bahwa kurikulum adalah sejumlah materi pelajaran yang harus ditempuh dalam suatu mata pelajaran atau disiplin ilmu tertentu, seperti kurikulum bahasa arab, kurikulum pendidikan bahasa inggris atau kurikulum ilmu pengetahuan sosial. ${ }^{12}$ Berdasarkan beberapa definisi diatas dapat disimpulkan bahwa kurikulum yaitu suatu perencanaan yang sudah disepakati bersama dalam hak mencapai suatu tujuan yang sama untuk mewujudkan hal-hal yang diharapkan.

2. Scientific

Untuk mengetahui pengertian sceintific terlebih dahulu harus dipahami pengertian ilmu. Ilmu dalam arti sceince dapat dibedakan dengan ilmu dalam arti pengetahuan (knowledge). Ilmu adalah pengetahuan yang sistimatik. Ilmu berfungsi sebagai alat bantu dalam mengatasi masalaah sehari-hari. Ilmu diharapkan membantu kita memerangi penyakit, membangun jembatan, mendidik anak, dan sebagainya.

Konsep ilmu secara filosofis dalam khazanah pemikiran islam dapat dijumpai pada pemikiran Taimiyah (661-728 H), Ushul Al-Fiqh. Memang ulama sebelum telah ada yang membahas ilmu secara filosofis seperti yang diungkapkan oleh Abu Ya'la (380-458 H), salah seorang sahabat Ahmad Bin Hambal.

Berpikir adalah kegiatan mental yang menghasilkan pengetahuan. Metode ilmiah yang menggabungkan berpikir deduktif dan induktif merupakan ekspresi mengenai cara kerja pikiran sehingga mempunyai sifat rasional dan teruji. Pengetahuan yang disusunya merupakan pengetahuan yang dapat diandalkan. Pengetahuan yang berupa ilmu itu dapat menjelaskan gejala alam empirik sehingga memungkinkan kita meramalkan apa yang akan terjadi. Berdasarkan atas ramalan itu, manusia dapat mengontrol dan mengendalikan gejala-gejala bahkan sebelum ia berubah menjadi kenyataan.

Berpikir deduktif memberi sifat rasional kepada pengetahuan ilmiah, sifat konsisten terhadap pengetahuan ilmiah dan terdapat pengetahuan yang telah ada atau yang telah dikumpulkan sebelumnya. Secara sistimatik dan kumulatif, pengetahuan ilmiah disusun setahap demi setahap dengan argumentasi mengenai sesuatu yang didasarkan atas pengetahuan yang telah ada. Secara teratur, konsisten dan koheren, ilmu mencoba memberikan penjelasan rasional kepada objek yang beradadalam fokus kajianya.

Pejelasan yang rasional dan koheren ini tidak memberikan kesimpulan yang bersifat pinal. Hal ini sesuai dengan hakikat rasionalisme yang bersifat pluralistik. Oleh karena itu, dimukinkan menyusun berbagai penjelasan terhadap suatu obejek pemikiran tertentu. Meskipun argumentasi rasional didasarkan pada premis-premis ilmiah yang telah teruji kebenaranya, namun dimungkinkan pula memilih sejumlah premis ilmiah yang tersedia yang

\footnotetext{
${ }^{12}$ Muhammad Zaini, Pengembangan Kurikulum (Yogyakarta: Teras, 2009), hlm.1-2
} 
digunakan dalam penyusunan argumentasi. Oleh karena itu, dipergunakanlah cara berpiki induktif yang didasarkan atas kreteria kebenaran korespondensial.

Teori korespondensi menyebutkan bahwa suatu pernyataan benar bila terdapat fakta-fakta empirik yang mendukung pernyataan tersebut. Sekiranya seseorang menyatakan bahwa "Salju Itu Berwarna Putih", maka pernyataan itu benar apabila terdapat kernyataan yang mendukung isi pernyataan tersebut, yakni bahwa empirik memang dapat diuji kebenaranya bahwa salju itu berwarna putih. Bagi mereka yang terbiasa melihat salju, pengujian itu tidaklah perlu penting. Akan tetapi bagi mereka yang belum pernah melihatnya, pengujiannya secara empirik menjadi sangat bermakna. ${ }^{13}$

Melihat penjelasan yang diatas, maka Pendekatan adalah konsep dasar yang mewadahi, menginspirasi, menguatkan, dan melatari pemikiran tentang bagaimana metode pembelajaran diterapkan berdasarkan teori tertentu. Oleh karena itu banyak pandangan yang menyatakan bahwa pendekatan sama artinya dengan metode.

Pendekatan ilmiah berarti konep dasar yang menginspirasi atau melatarbelakangi perumusan metode mengajar dengan menerapkan karakteristik yang ilmiah. Pendekatan pembelajaran ilmiah (scientific teaching) merupakan bagian dari pendekatan pedagogis pada pelaksanaan pembelajaran dalam kelas yang melandasi penerapan metode ilmiah.

Pengertian penerapan pendekatan ilmiah dalam pembelajaran tidak hanya fokus pada bagaimana mengembangkan kompetensi siswa dalam melakukan observasi atau eksperimen, namun bagaimana mengembangkan pengetahuan dan keterampilan berpikir sehingga dapat mendukung aktivitas kreatif dalam berinovasi atau berkarya. Maka dari pemaparan diatas dapat kita tarik kesimpulan bahwa pendekatan scientific yaitu suatu pendekatan yang dilakukan secara nyata dan ril.

Adapun langkah-langkah Pembelajaran dengan mengunakan pendekatan saintifik yaitu: (1) Mengamati, (2) Menanya, (3) Menalar dan (4) Mencoba. ${ }^{14}$

3. IPA

Ilmu dalam bahasa Inggris: natural science; atau ilmu pengetahuan alam adalah istilah yang digunakan yang merujuk pada rumpun ilmu dimana obyeknya adalah benda-benda alam dengan hukum-hukum yang pasti dan umum, berlaku kapan pun dimana pun. ${ }^{15}$

Pembelajaran IPA ialah suatu pembelajaran kepada peserta didik yang mempelajari tentang pengetahuan tentang alam. IPA sebagai aplikasi merupakan penerapan metode atau kerja ilmiah dan konsep sains dalam 2002),Hlm.,4-8

${ }^{13}$ Juhaya S. Praja, Filsafat Dan Metodologi Ilmu Dalam Islam, (Jakarta Selatan, Teraju:

${ }^{14}$ Pendekatan Pembelajaran Sceintific Di Kurikulum 2013

${ }^{15}$ http://id.wikipedia.org/wiki/llmu_alam, diakses tanggal 4 April 2014. 
kehidupan sehari-hari. IPA sebagai sikap merupakan rasa ingin tahu tentang objek, fenomena alam, makhluk hidup, serta hubungan sebab akibatnya yang menimbulkan masalah baru yang dapat dipecahkan melalui prosedur yang benar.

Pembelajaran IPA di SD Pembelajaran merupakan persiapan di masa depan, dalam hal ini masa depan kehidupan anak yang ditentukan orang tua. Oleh karenanya, sekolah mempersiapkan mereka untuk hidup dalam masyarakat yang akan datang. Pembelajaran merupakan suatu proses penyampaian pengetahuan, yang dilaksanakan dengan menuangkan pengetahuan kepada siswa. Bila pembelajaran dipandang sebagai suatu proses, maka pembelajaran merupakan rangkaian upaya atau kegiatan guru dalam rangka membuat siswa belajar. Proses tersebut dimulai dari merencanakan progam pengajaran tahunan, semester dan penyusunan persiapan mengajar (lesson plan) berikut persiapan perangkat kelengkapannya antara lain berupa alat peraga dan alat-alat evaluasinya.

Berdasar beberapa pendapat diatas maka disimpulkan pembelajaran adalah suatu proses dan rangkaian upaya atau kegiatan guru dalam rangka membuat siswa belajar, pembelajaran juga merupakan persiapan di masa depan dan sekolah mempersiapkan mereka untuk hidup dalam masyarakat yang akan datang. Ilmu Pengetahuan Alam merupakan mata pelajaran di SD yang dimaksudkan agar siswa mempunyai pengetahuan, gagasan dan konsep yang terorganisasi tentang alam sekitar, yang diperoleh dari pengalaman melalui serangkaian proses ilmiah antara lain penyelidikan, penyusunan dan penyajian gagasan-gagasan.

IPA adalah pengetahuan khusus yaitu dengan melakukan observasi, eksperimentasi, penyimpulan, penyusunan teori dan demikian seterusnya kaitmengkait antara cara yang satu dengan cara yang lain. IPA berhubungan dengan cara mencari tahu tentang alam secara sistematis, sehingga IPA bukan hanya penguasaan kumpulan sistematis dan IPA bukan hanya penguasaan kumpulan pengetahuan yang berupa fakta-fakta, konsep-konsep atau prinsip-prinsip saja, tetapi juga merupakan suatu proses penemuan.

Menurut Iskandar IPA adalah ilmu yang mempelajari peristiwa-peristiwa yang terjadi alam. Ilmu Pengetahuan Alam merupakan mata pelajaran di SD yang dimaksudkan agar siswa mempunyai pengetahuan, gagasan dan konsep yang terorganisasi tentang alam sekitar, yang diperoleh dari pengalaman melalui serangkaian proses ilmiah antara lain penyelidikan, penyusunan dan penyajian gagasan-gagasan. Pada prinsipnya, mempelajari IPA sebagai cara mencari tahu dan cara mengerjakan atau melakukan dan membantu siswa untuk memahami alam sekitar secara lebih mendalam.

Dari beberapah pendapat di atas maka dapat disimpulkan pembelajaran IPA adalah ilmu yang mempelajari peristiwa-peristiwa yang terjadi di alam dengan melakukan observasi, eksperimentasi, penyimpulan, penyusunan teori agar siswa mempunyai pengetahuan, gagasan dan konsep yang terorganisasi 
tentang alam sekitar, yang diperoleh dari pengalaman melalui serangkaian proses ilmiah antara lain penyelidikan, penyusunan dan penyajian gagasangagasan.

Adapun tujuan pembelajaran IPA di SD agar siswa: 1) Mengembangkan rasa ingin tahu dan suatu sikap positif terhadap sains, teknologi dan masyarakat. 2) Mengembangkan keterampilan proses untuk menyelidiki alam sekitar, memecahkan masalah dan membuat keputusan. 3) Mengembangkan pengetahuan dan pemahaman konsep-konsep sains yang akan bermanfaat dan dapat diterapkan dalam kehidupan sehari-hari. 4) Mengembangkan kesadaran tentang peran dan pentingnya sains dalam kehidupan sehari-hari. 5) Mengalihkan pengetahuan, keterampilan dan pemahaman ke bidang pengajaran lain. 6) Ikut serta dalam memelihara, menjaga dan melestarikan lingkungan alam. Menghargai berbagai macam bentuk ciptaan Tuhan di alam semesta ini untuk dipelajari. ${ }^{16}$

\section{Hasil Penelitian}

\section{Persepsi guru Sekolah Dasar Muhammadiyah Demangan Yogyakarta tentang pendekatan saintifik}

Pembelajaran di SD Muhammadiyah Demangan Yogyakarta sudah menggunakan pendekatan saintifik sebelum datangnya kurikulum 2013, tetapi bentuknya bukan seperti yang sekarang diharuskan. Sekolah Dasar Muhammadiyah Demangan Baru kurikulum 2013 semua mata pelajaran menggunakan pendekatan saintifik, sehingga pembelajarannya benar-benar diharuskan siswa untuk mengetahui apa yang di pelajari tersebut. Kurikulum 2013 guru lebih dituntut untuk mempersiapkan media pembelajaran dengan baik, membuat anak bertanya, mengamati, mengadakan eksperimen, menemukan fakta dan konsep sendiri.

Guru di SD Muhammadiyah Demangan Yogyakarta sebagian sudah banyak mengikuti pelatihan dan workshop seperti implementasi kurikulum 2013 sehingga tidak diragukan lagi pemahaman guru tentang kurikulum 2013. Sarana dan prasarana di SD Muhammadiyah juga sangat memadai, seperti Laboratorium Komputer, perpustakaan dan media pembelajaran.

Sekolah Dasar Muhammadiyah mempunyai tradisi yang turun temurun, seperti bersalaman ketika datang sekolah. Guru diharuskan datang lebih awal dari siswanya, semua guru berjajar di dalam halaman sekolah seperti orang berbaris

\footnotetext{
${ }^{16}$ http://cumanulisaja.blogspot.com/2012/10/hakekat-pembelajaran-ipa-di-sd.html. Diakses tanggal 4 April 2014.
} 
menunggu datang siswanya, siswa bersalaman ke semua guru yang sudah menuggunya, ini dilakukan setiap hari. ${ }^{17}$

Berdasarkan wawancara dengan beberapa guru di SD Muhammadiyah, semua guru di SD Muhammadiyah sudah memahami konsep pendekatan saintifik. Tanggapan guru SD Muhammadiyah terkait dengan pendekatan saintifik yaitu :

Ibu Syarifah S.Pd, guru kelas VI, dia mendefinisikan pendekatan saintifik

" kita memberikan ilmu, kemudian anak yang menemukan sendiri gitu, artinya kita hanya menggiring saja, jadi siswa lebih aktif. Selain itu di dalam pendekatan saintifik itu kan ada proses, anak mempraktekkan, kemudian anak menyimpulkan sendiri dan melakukan observasi."18

Berdasarkan penjelasan tersebut, di dalam proses pembelajaran, guru hanya sebagai pemberi ilmu atau pasilitator, selanjutnya siswa di tuntut lebih aktif di kelas. Aktif dalam arti bertanya, mencoba, menalar, sehingga proses pembelajarannya menjadi lebih aktif dan pembelajaran lebih didominasi oleh siswa.

Guru selama proses pembelajaran berlansung hanya sebagai fasilitator, siswa lebih ditekankan untuk aktif dan mengembangkan sendiri, dengan seperti itu siswa bisa menjadi aktif dibandingkan dengan tidak memberikan kesempatan kepada siswa untuk mengembangkan ilmunya.

Ibu Sarifah berpendapat, di dalam pendekatan saintifik itu ada proses. Proses yang dimaksud seperti observasi, menanya, menalar, bertanya dan mengumpulkan informasi. Siswa selama proses pmebelajaran berlangsung lebih ditekankan untuk bisa membuat kesimpulan sendiri, dengan harapan bisa terbiasa membuat kesimpulan sendiri dengan pola pikirannya. Siswa juga ditekankan untuk melakukan observasi dimulai dari yang lebih sederhana dan melakukannya dengan langkah-langkah dalam observasi seperti:

a. Guru dan siswa Menentukan terlebih dahulu objek yang akan diobservasi, sehingga proses observasinya menjadi lebih terarah dan jelas apa tujuan dari observanya itu.

b. Guru dan siswa membuat pedoman wawancara sesuai dengan objek yang akan diobservsi.

c. Guru dan siswa melakukan secara jelas data-data yang perlu di observasi, baik primer maupun skunder.

d. Guru dan siswa menentukan terlebih dahulu lokasi yang akan menjadi objek obserasi, sebab tanpa adanya objek maka observasi tidak bisa dilakukan.

e. Guru dan siswa menentukan secara jelas bagaimana observasi akan dilakukan untuk mengumpulkan data agar berjalan mudah dan lancar.

\footnotetext{
${ }^{17}$ Hasil wawancara dengan guru kelas IV Pak Kastowo S.Pd, pada hari selasa, 5 januari 2015, pukul 10:10-10:30.

${ }^{18}$ Hasil wawancara pada hari selasa tanggal 17 Januari 2015. jam 10:00-10:25
} 
f. Guru dan siswa menentukan pencatatan atas hasil observasi, seperti menggunakan buku catatan, kamera, tape recorder, vidio perekam, dan alat-alat tulis.

Metode observasi jika dilakukan dengan memperhatikan langkah-langkah diatas, siswa menjadi baik dan bisa dipertanggung jawabkan hasil observasinya sebab menggunakan langkah-langkah obaservasi yang benar.

Berdasarkan pendapat ibu Syarifah tersebut diatas maka dapat disimpulkan, pendekatan saintifik dapat memberikan kesempatan kepada siswa yang seluasluasnya untuk mengembangkan ilmunya, dengan cara seperti itu siswa menjadi aktif dan pemahamannya menjadi lebih luas.

Pendapat tersebut hampir sama dengan pak Triyanto, dia mendefinisikan pendekatan saintifik

"pendekatan yang di dalamnya mengandung mengamati, menanya, mencoba, menyimpulkan" sedangkan dalam prosesnya Itu kan dengan cara pengamatan, memberikan sebuah proses pembelajaran. Dalam kurikulum 2013 sebenarnya dalam konteks teorinya sih bagus, tetapi, karena disitu mencakup keseluruhan dari apa-apa yang bisa kita berikan, sehingga anak bisa berkembang secara mandiri, tidak harus tunggu di jelaskan tetapi mencari sendiri. Dengan kita memberikan bahan/alat untuk mengamati, untuk dia mencari tahu, apa yang dia tidak tahu di tanyakan dengan sendirinya akan muncul apa yang dia cari gitu lo, ya tidak harus di jelaskan dengan cara ceramah". ${ }^{19}$

Pak triyanto berpendapat, guru hanya memberikan bahan/media kepada siswa selanjutnya siswa yang lebih banyak aktif dalam hal pembelajaran, selain itu siswa dituntut untuk lebih aktif dan banyak mencari sendiri materi yang terkait dengan pokok bahasan tersebut, siswa menemukan sesuatu yang tidak diketahui baru ditanyakan kepada rekan atau gurunya, supaya apa yang menjadi kebingunganya tersebut bisa terjawab, dengan seperti itu perkembangan siswa semakin maju dan tidak selalu tergantung kepada gurunya.

Implementasi pendekatan saintifik siswa lebih aktif dibandingkan dengan guru, guru sebagai penyaji selanjutnya siswa yang mencari sediri dan mengalami sendiri ketika melakukan observasi. Sistem belajar seperti itu bisa memberikan pengalaman secara langsung kepada siswa dan bila siswa mendapatkan kesulitan maka siswa menanyakan kepada guru terkait dengan apa yang menjadi kesulitanya tersebut.

Pak Kastowo, dia mendefinisikan pendekatan saintifik

" pendekatan yang dimulai dari pengamatan dulu, terus pertanyaan, kemudian percobaan, kemudian menyimpulkan dan nanti akan tahu hasilnya itu lebih baik". ${ }^{20}$

Menurut pendapat di atas, pendekatan saintifik dimulai dari percobaan, dimana percobaan atau exsperimen yaitu kegiatan terinci yang direncanakan untuk

\footnotetext{
${ }^{19}$ Hasil wawancara pada hari selasa tanggal 17 januari 2015, jam 10:30-11:00

${ }^{20}$ Hasil wawancara pada hari selasa tanggal 5 januari 2015. jam 10:10-10:30
} 
menghasilkan data untuk menjawab suatu masalah atau menguji suatu hipotesis. Experimen merupakan jawaban dari suatu hipotesis atau dugaan ayng sudah dibuat oleh guru atau siswa, seperi pada pokok bahasan gundukan yang mempunyai pohon atau rumput dengan yang tidak mempunyai rumput bila dialiri air apa yang akan terjadi terhadap dua gundukan tersebut. Siswa untuk mengetahui jawaban itu harus melakukan experimen apakah gundukan yang mempunyai rumput tersebut akan hancur atau sebaliknya. Hasil percobaan atau exsperimen tersebut siswa bisa membuat kesimpulan sendiri berdasarkan pengamaanya masing-masing.

siswa sebelum melakukan exsperimen terlebih dahulu memperhatikan seperti : a) siswa harus mengadakan percobaan, maka jumlah alat, bahan atau materi percobaan harus cukup bagi siswa. b) Agar eksperimen itu tidak gagal dan siswa menemukan bukti yang menyakinkan atau memungkinkan hasilnya tidak membahayakan, maka kondisi alat dan mutu bahan percobaan yang digunakan harus baik dan bersih. c) siswa perlu teliti dan konsentrasi dalam mengamati proses percobaan, maka perlu adanya waktu yang cukup lama sehingga mereka menemukan pembuktian kebenaran dari teori yang dipelajari tersebut. d) Siswa dalam eksperimen adalah sedang belajar dan berlatih, maka perlu diberi petunjuk yang jelas, sebab mereka di samping memperoleh pengetahuan, pengalaman serta keterampilan, juga kematangan jiwa dan sikap perlu diperhitungkan oleh guru dalam memilih objek eksperimen itu.

Melihat dari beberpa hal-hal yang perlu diperhatikan tersebut, peran guru sangat diperlukan, sebab dengan bimbingan guru yang profesional maka hasil dari exsperimen siswa menjadi baik dan bisa dipertanggung jawabkan secara ilmiah. Selain dari hasil tersebut, siswa juga bisa membuat kesimpulan secara baik dan benar berdasarkan dari hasil experimenya tersebut.

Siswa di dalam pendekatan saintifik, diarahkan untuk mengamati suatu benda, dari pengamatan tersebut, akan muncul pertanyaan-pertanyaan dari siswa, dengan pertanyaan tersebut siswa semakin bertambah pengetahuannya terhadap apa yang sedang diamati. Siswa melakukan percobaan-percobaan, dari percobaan tersebut siswa mendapatkan kegiatan yang lebih baik dibandingkan dengan tidak menggunakan langkah-langkah tersebut dalam pembelajaran.

Adapun menurut Kepala Sekolah SD Muhammadiyah:

"di dalam pendekatan saintifik itu kan ada menalar, adanya menanya, mendiskusikan dan mengomunikasikan" 21

berdasarkan pendapat di atas, pendekatan saintifik yang ada unsur menalar, menanya, mendiskusikan dan mengomunikasikan. Siswa di dalam kegiatan menalar, diberikan kesempatan untuk mengeluarkan pendapatnya seluas-luasnya sehingga siswa menjadi lebih aktif dalam hal pembelajaran begitu juga dengan menanya. Menanya merupakan awal siswa untuk mengetahui hal-hal yang dipelajari. Siswa dalam menanya khususnya di kelas rendah (I dan II) masih sulit

\footnotetext{
${ }^{21}$ Hasil Wawancara Pada Hari Selasa Tanggal 5 januari 2015. Jam 09:30-10:00
} 
untuk melakukan pertanyaan, ini yang menjadi keluhan bagi para guru dalam implementasi pendekatan saintifik tersebut, begitu juga di kelas tinggi.

Berdasarkan beberapa pendapat di atas, maka dapat disimpulkan, guru SD Muhammadiyah Demangan Baru Yogyakarta sudah mengetahui dan memahami konsep dari pada pendekatan saintifik, seperti langkah-langkah dalam pembelajaran dan menggunakan pendekatan saintifik didalam proses pembelajaran.

Langkah-langkah menggunakan pendekatan saintifik, semua guru sudah mengetahui bila dilihat dari hasil wawancara di atas, dimana siswa harus mengamati/observasi, menanya, membuat kesimpulan, dan lain-lain. Guru di SD Muhammadiyah sudah menggunakan pendekatan saintifik dalam proses pembelajaran.

Kelebihan dalam pembelajaran dengan menggunakan pendekatan saintifik, seperti yang dikatakan oleh Pak Kastowo, S.Pd, guru kelas IV pada hari Selasa tanggal 5 januari jam 10:00-10:30.

"Dengan menggunakan pendekatan saintifik siswa mencoba dan hasilnya yang nyata, jadi anak tidak mengira-ngira, hasilnya lebih kongkrit dan lebih baik".

Berdasaraka pendapat tersebut, dalam proses pembelajaran dengan menggunakan pendekatan saintifik siswa diarahkan untuk melakukan percobaan atau exsperimen terkait dengan pokok bahasan yang diajarkan kemudian hasilnya tersebut bisa dipertanggung jawabkan dengan mengabdikan dokumen-dokumen seperti photo, dengan seperti itu maka anak tidak dibuat mengira dalam hal pembelajran, siswa merasakan langsung pembelajarannya dan langsung berhadapan dengan media pembelajaran tersebut, selanjutnya ini akan berdampak positif pada hasil kerja siswa, baik itu dari kesimpulan dan tugas yang diberikan oleh gurunya. Pak Triyanto juga mengatakan :

"Dengan pendekatan saintifik, anak bisa berkembang secara mandiri, tidak harus tunggu dijelaskan tetapi mencari sendiri selain itu Lebih mudah anakanak diarahkan, anak-anak mencari tahu.”.

Berdasarkan penjelasan pak Triyanto tersebut, peserta didik bisa secara mandiri dalam mencarai sumber lain terkait dengan sub pokok bahasan seperti ke perpustakaan, dengan seperti itu anak menjadi lebih kreatif tidak hanya menunggu dijelaskan oleh guru. Pak Triyanto juga mengatakan siswa lebih mudah diarahkan atau diajarkan karena sudah mencari terlebih dahulu sumber-sumber yang lain seperi dari koran, buku dan lewat internet sehingga dalam proses pembelajarannya lebih menyenangkan guru hanya mengarahkan, bila siswa mendapatkan kesulitan dia mengajukan pertanyaan keteman sejawat atau kegurunya langsung.

Menggunakan pendekatan saintifik siswa lebih rajin dalam mencari sumber sendiri. Guru menyiapkan bahan, kemudian siswa yang mengembangkannya. 
Guru di dalam kelas mengawasi kegiatan siswa dan membimbingnya, dimana tempat siswa tidak mengerti maka bisa ditanyakan.

Pak triyanto juga menambahkan:

"Dengan menggunakan pendekatan saintifik, guru lebih santai, sebab siswa yang lebih aktif dalam proses pembelajaran, guru hanya membimbing, mengarahkan, bila pendekatan saintifik itu benar-benar di terapkan". ${ }^{22}$

Pendekatan saintifik bila digunakan oleh guru atau sekolah dalam proses pembelajaran, guru lebih santai sebab guru hanya mengarahkan saja atau memberikan jalan kepada siswa kemana arah proses pembelajarannya sehingga guru menjadi lebih santai dibandingkan dengan pendekatan-pendekatan yang lain.

Pendekatan saintifik sangat mudah dan guru lebih santai bila benar-benar di terapkan dengan sebaik-baiknya, Ibu Syarifah S.Pd, guru kelas VI mengatakan sebaliknya .

"Dalam proses pembelajaran di kelas VI semester II, bukan siswa yang lebih aktif akan tetapi guru, karena di kejar oleh waktu".

Berdasarkan penjelasan di atas, waktu di kelas VI lebih sedikit dibandingkan dengan kelas V kebawah, disebabkan kelas VI waktu untuk mempelajari materi lebih sedikit, karena waktunya di gunakan untuk mempersiapkan Ujian Nasional, itu sebabnya waktu menjadi lebih sedikit dibandingkan dengan adek-adek kelasnya.

Proses pembelajaran dengan menggunakan pendekatan saintifik, berdasarkan hasil wawancara dengan kepala sekolah pada hari Selasa tangal 5 Januari 2015 pukul 09:30-10:00,

"Pembelajaran dengan menggunakan pendekatan saintifik khususnya di kelas I dan II itu masih sulit, karena tidak tahu apa yang harus dia tanyakan, dia amati, dan juga untuk memancing siswa untuk bertanya, akan tetapi di kelas-kelas atas (III, IV, V, VI) sudah bisa, karena sudah paham apa yang harus dia tanyakan".

Ibu Syarifah S.Pd, guru kelas VI juga mengatakan

"Ketika kita menemukan anak yang kurang aktif, kreatif, ya sulit juga mas, jadi cara mengatasinya ya memancing emosi anak-anak dengan memberikan pertanyaan-pertanyaan".

Dari pendapat di atas antara Kepala Sekolah dengan Ibu Syarifah, ada kejanggalan. Ibu Kepala Sekolah mengatakan tempat sulit hanya di kelas I dan II, sebab siswa sulit untuk bertanya sedangkan di kelas selanjutnya sudah bisa. Sedangkan Ibu Syarifah mengatakan,

"Kita kesulitan ketika menemukan siswa yang tidak aktif".

Siswa yang tidak aktif bukan hanya terdapat di kelas I dan II akan tetapi terdapat juga di kelas VI. Ibu Syarifah dan kepala sekolah mempunyai kesamaan cara

\footnotetext{
${ }^{22}$ Hasil wawancara pada hari selasa tanggal 17 januari.
} 
untuk mengatasinya dengan memancing siswa untuk bertanya, dengan cara seperti itu siswa akan menjadi aktif di dalam kelas.

Berdasarkan penjelasan di atas, dapat disimpulkan, pembelajaran dengan menggunakan pendekatan saintifik di SD Muhammadiyah sudah berjalan dengan baik dan menggunakannya di dalam proses pembelajaran, itu terbukti dari hasil wawancara dan beberapa gambar dalam melakukan pembelajaran.

\section{Pelaksanaan pendekatan saintifik dalam pembelajaran IPA.}

Implementasi pendekatan saintifik pembelajaran IPA pada tema 6 sub tema 2 pokok bahasan 3 prediksi atau perkiraan antara gundukan yang ada tumbuhan dengan yag tidak ada.

\section{Pelaksanaan pembelajaran.}

\section{Kegiatan awal}

Berdasarkan dari hasil observasi, kegiatan pembelajaran pada pokok bahasan prediksi gundukan dilaksanakan di dalam kelas. Sebelum memulai proses pembelajran terlebih dahulu siswa melakukan sholat dhuha secara berjamaah di musholla sekolah, akan tetapi pada saat itu siswa kelas IV tidak mendapatkan giliran untuk sholat dhuha sehingga dia membaca al-qur'an di dalam kelasnya.

Sekolah Dasar Muhammadiyah Demangan Yogyakarta merupakan salah satu sekolah yang selalu mengedepankan agama. Siswa sebelum masuk kelas terlebbih dahulu sholat dhuha secara berjama'ah di musholla SD dan membaca al-qur'an di dalam kelas masing-masing.

$\underline{\text { Kegiatan inti }}$

Kegiatan inti implementasi pendekatan saintifik pada muatan IPA pokok bahasan memprediksi gundukan adalah sebagai berikut:

a) Pengamatan

Pembelajaran IPA pokok bahasan gundukan, pada kegiatan awal guru menanyakan kepada siswa tentang gundukan seperti di bawah ini:

Guru : Apa itu gundukan?

Siswa I : Tanah yang bertumpuk-tumpuk pak.

Siswa II : Tanah yang lebih tinggi sedikit.

Siswa III : Tanah yang seperti gunung.

guru melakukan tanya jawab seperti itu untuk mengetahui kemampuan awal siswa, sejauh mana pemahamannya tentang gundukan, sehingga pada proses pembelajaran nantinya siswa dapat membangun pengetahuan tentang gundukan. Melihat dari jawaban siswa tersebut, maka sebagian dari siswa sudah mengetahui apa itu gundukan dan ini sangat bermanfaat dalam berlangsungnya proses pembelajaran. Selain itu guru memberikan penjelasan tentang gundukan kepada siswa, agar siswa lebih memahami tentang gundukan. b) Menanya. 
Guru memberikan kesempatn kepada siswa untuk mengembangkan pertanyaan seputar gundukan. Guru sebagai langkah awalnya memberikan stimulasi kepada siswa, memberikan pertanyaan dasar seputar gundukan.

Guru : Bila terjadi hujan, maka pada gundukan tanah yang mempunyai rumputan atau pohan airnya diserap oleh pohon atau tidak?

Siswa : Diserap pak.

Guru : Bagaimana dengan yang tidak mempunyai pohon?

siswa : Tidak ada yang menyerapnya pak.

Guru : Terus bagaimana bentuk gundukan yang mempunyai rumput atau pohon, apakah akan tetap atau meleleh ?

Siswa : Tetap pak.

Guru : Terus bagaimana dengan yang tidak mempunyai pohon atau rumput

siswa I : Tanahnya akan meleleh pak,

Siswa II :Hancur pak,

Siwa III : Tidak berbentuk lagi pak.

Siswa diminta nntuk bergantian mengajukan pertanyaan seputar gundukan. Pertanyaan tidak selalu dijawab oleh guru, guru juga meberikan kesempatan kepada siswa untuk menjawab pertanyaan temannya. Kegiatn ini berlangsung beberapa menit sampai tidak ada lagi siswa yang bertanya.

\section{c) Menalar}

Siswa sudah mengetahui tetang manfaat akar bagi tanah yaitu untuk menyerap air, untuk mencegah terjadinya longsor. diharapkan siswa tidak sembarangan menebang pohon, sebab dapat berdampak buruk bagi manusia. Guru juga bisa mengajak siswanya untuk melakukan penghijauan demi menjaga alam dari bahaya, seperti tanah longsor dan banjir. Pembelajaran dengan seperti itu pada pokok bahasan menalar gundukan dapat bermanfaat bagi siswa.

d) Mencoba

Mencoba merupakan kegiatan yang membutuhkan eksen, selain itu juga membutuhkan media. Proses pembelajaran di kelas IV guru kurang sekali memberikan kesempatan kepada siswa untuk melakukan eksperimen atau percobaan. Guru juga tidak membawakan media kedalam kelas yang terkait dengan pokok bahasan pada saat proses pembelajara, sehingga kegiatan mencoba ini jarang dilakukan oleh siswa.

Sekolah dasar Muhammadiyah pada kelas IV pada pembelajaran IPA kegiatan mencoba, guru belum sepenuhnya menggunakan pendekatannya dalam proses pembelajaran, disebabkan oleh beberapa faktor, seperti guru belum kreatif membuat media pembelajaran, membutuhkan biaya besar untuk mendatangkan media tersebut dan waktu yang selalu sedikit.

e) Membentuk jejaring (Networking) 
Membentuk jejaring pada muatan IPA pokok bahasan memprediksi dapat ditemukan pada bagaimana siswa memberikan kesimpulan terkait dengan materi pembelajaran, selain itu bisa juga dilihat pada keberanian siswa mengungkapkan secara lisan hasil kesimpulannya.

\section{Kendala yang dihadapi ketika menggunakan pendekatan saintifik.}

Berbagai model pendekatan pembelajaran, apakah itu CTL, PAIKEM, PAKEM, saintifik, dan lain-lain, semuanya tergantung dari situasi dan keadaan pendekatan tersebut diterapkan. Seseorang tidak bisa mengatakan bahwa pendekatan ini paling cocok, akan tetapi dilihat terlebih dahulu dimana pendekatan tersebut diterapkan, pada mata pelajaran apa pendekatan diterapkan, selain itu siswanya seperti apa, apakah akan bisa mengerti dengan pendekatan ini, itu yang menjadi pertimbangan dalam memilih pendekatan. Selain faktor tersebut, guru juga sangat menentukan apakah guru tersebut sudah paham betul dengan pendekatan yang akan digunakan, selain itu apa guru sudah membaca terkait dengan penelitian yang sudah menggunakan pendekatan tersebut.

Pendekatan saintifik merupakan salah satu dari sekian banyak pendekatan yang digunakan dalam dunia pendidikan. Dalam hal implementasinya sudah tentu ada kendala-kendala dalam hal pelaksanaanya, apakah itu dari guru sendiri atau dari siswa. Adapun kendala pada implementasi pendekatan saintifik di SD Muhammadiyah bisa diihatnya dari dua sisi yaitu dari guru sendiri dan dari siswanya.

Guru di SD Muhammadiyah Demangan Baru ketika melakukan implementasi pendekatan saintifik dalam proses pembelajaran yang menjadi kendala sebagaimana yang dikatan oleh pak kastowo:

"Terkait sarana prasarana memang ini kita terkendala sekali karna peralatan. Peralatan-peralatan yang IPA itu agak kurang untuk perakteknya, kalau hanya KIT, KIT itu yang batu-batuan ya mungkin,tetapi memakai yang lain-lainya itu kita kurang. Untuk mengatasi hal kekurangan dalam praktek, apakah ada langkah-langkah yang dilakukan baik dari guru, sekolah atau pemerintah pak? ini yang praktek itu kalau kurikulum 2013 terus terang saja dari pemerintah itu belum ada, ya sekolah menyediakan sendiri, berusaha sendiri apa yang mau dipakai ya sudah kita mengeluarkan biaya sendiri untuk mencarinya, jadi pemerintah belum ada untuk yang kurikulum 2013 jadi mungkin fokusnya mungkin baru ini proses pembelajaranya itu, tapi yang untuk prakteknya belum, mungkin belum dipikirkan".

Berdasarkan hasil wawancara tersebut, kendala yang paling sering dihadapi oleh guru yaitu terkait dengan alat dalam prakterk, sebab dalam melakukan experimen guru dan siswa membutuhkan yang namanya alat dan bahan, akan tetapi dari pemerintah tidak ada bahan dan alat yang disediakan sehingga guru merasa kesulitan dalam hal melakukan exsperimen. Mengantisipasi tersebut, sekolah mengeluarkan biaya melalui dana Bantun 
Oprasional Sekolah (BOS), akan tetapi sebelum ada dana BOS sekolah mengelaurkan sendiri dari anggaran sekolah dan biayanya lumayan besar.

Selain darai bahan dan alat yang menjadi keluar para guru dalam ipleenasi pendekatan saintifik selama proses pembelajran, selanjtnya terkait dengan waktu dan penilaian.

"Itu kan dengan cara pengamatan, memberikan sebuah proses pembelajaran. Dalam kurikulum 2013 sebenarnya dalam konteks teorinya sih bagus, tetapi, karena disitu mencakup keseluruhan dari apa-apa yang bisa kita berikan, sehingga anak bisa berkembang secara mandiri, tidak harus tunggu di jelaskan tetapi mencari sendiri. Dengan kita memberikan bahan/alat untuk mengamati, untuk dia mencari tahu, apa yang dia tidak tahu di tanyakan dengan sendirinya akan muncul apa yang dia cari gitu lo, ya tidak harus di jelaskan dengan cara ceramah, kelemahannya itu satu, keterbatasan waktu dan proses penilaian”.

Berdasarkan hasil wawancara dengan pak triyantor tersebut diatas, dalam hal teori sangat baik seperti guru tidak hanya menggunakan metode ceramah akan tetapi mengguakan pendekatan-pendekatan yang lain, akan tetapi dalam waku proses pembelajarannya waktu yang diberikan per sub tema hanya satu jam (2x35 menit), sehingga proses pembelajrannya kurang efesian, sedangkan utnuk melakukan obsevasi, experimen, menalar, membuat kesimpulan membutuhkan waktu minimal dua jam. Mengatasi kekurangan waktu tersebut guru melakukan observasi diluar jam sekolah seperti waktu libur, guru dan siswa pergi ke kebun binatang untuk melakukan observasi terkait dengan binatang jika pokok bahasannya tentang hewan, dalam observasi tersebut gur menyediakan lembar observasi yang harus diisi oleh siswa, setelah siswa selesai mengerjakannya diserahkan kembali ke gurunya sebagai nilainya.

Guru juga merasa kesulitan dalam hal penilian, bila kita melihat dalam bentuk penilaianya, guru harus menilai siswa setiap hari mulai dari dalam sekolah dan luar sekolah, sehingga guru merasa kusilatan dan dalam menyipkan bahan pembelajarannya menajdi tidak fokus dan ini bisa menajdi kendala dalam impleemasi pendeaktan saintifik.

Berdasarkan penjelasan diatas, maka disimpulkan kendala-kendala yang dihadapi guru dalam implementasi pendekatan saitifik yaitu :

a. Waktu

Waktu merupakan hal yang sangat penting dalam hal pembelajaran, dengan waktu pembelajaran bisa maksimal dan juga tidak maksimal. Hal tersebut dapat berimbas terhadap pendekatan yang digunakan. Guru dalam hal implementasi pendekatan saintifik, ini yang menjadi kendalanya. Waktu per pokok bahasan hanya satu jam, sedangkan waktu yang dibutuhkan minimal dua jam per pokok bahasan sebab akan melakukan pengamatan.

b. Siswa kurang aktif 
Berdasarkan hasil wawancara di SD Muhammadiyah, yang menjadi kendala selama proses pembelajaran dengan menggunakan pendekatan saintifik dimana ketika seorang guru menemukan siswa yang kurang aktif, tidak mau bertanya, malas dan kurang respon terhadap pembelajaran.

c. Media pembelajaran

Pengadaan media juga menjadi kendala dalam hal implementasi pendekatan saintifik, dimana tidak semua media pembelajaran bisa dibawa kesekolah, seperti sawah, gunung dan hutan, itu semua tidak mungkin guru membawanya ke sekolah. Sedangkan dalam hal pendekatan saintifk faktanya siswa dihadapkan dengan hal-hal yang nyata. Maka untuk mengatasi semua itu, siswa dan guru melakukan pembelajaran diluar jam kelas, seperti hari libur, pergi bertamasya ke tempat yang sudah dipelajarinya sambil guru memperkenalkan kepada siswa. Sedangkan untuk membawa siswa keluar tersebut membutuhkan biaya banyak, untuk itu ini juga menjadi kendala dalam hal implementasi pendekatan saintifik.

d. Dari siswa

Berdasarkan hasil perbincangan dengan siswa ketika selesai pembelajaran, siswa merasa kesulitan dimana ketika mengerjakan tugas atau latihan, sebab tidak semua jawaban pada lembar bacaan yang diberikan ada, akan tetapi ada juga yang ada. Ini menjadi kendala yang dirasakan oleh siswa dalam hal pembelajaran dengan pendekatan saintifik. Selain itu, siswa juga merasakan dengan menggunakan pendekatan saintifik buku LKS belum juga datang yang dari pemerintah, sehingga proses pembelajarnnya kurang maksimal. Ini juga yang menjadi kendala dalam hal implementasi pendekatan saintifik.

\section{Kesimpulan}

Berdasarkan pembahasan dan analisis di atas, penelitian di SD Muhammadiyah dalam implementasi pendekatan saintifik kurikulum 2013 pada pembelajaran IPA dapat disimpulkan sebagai berikut:

1. Berdasarkan hasil wawancara, Persepsi guru di SD Muhammadiyah tentang pendekatan saintifik bagus. Guru sudah mengetahui dan mengerti tentang teori dan konsep pendekatan saintifik, sebab guru di SD Muhammadiyah sudah beberapa kali mengitui pelatihan dan wokshop. Pemahaan dan terori tentang pendekatan saintifik sudah tidak diragukan lagi.

2. Berdaarkan hasil observasi, implementasi pendekatan saintifik di SD Muhammadiyah pada pembelajaran IPA. Guru sudah melakukan proses pembelajaran sesuai dengan cara dan prosedurunya mulai dari observasi, menanya, menalar dan membuat jejaring. Guru dalam implementasi pendekatan saintifik ada beberapa yang belum sempurna dilakukan dalam proses pembelajaran tersebut, seperti dalam hal mengamati, guru kurang sekali membawakan media pada saat proses pembelajaran. Melihat hal seperti itu, 
implementasi pendekatan saintifik di SD Muhammadiyah belum sepenuhnya sempurna di terapkan dalam proses pembelajaran.

3. Berdasarkan hasil wawancara, kendala yang dihadapi guru seperti:

a. Waktu yang sangat sedikit sehingga proses pembelajarannya menjadi kurang efisien.

b. Selain waktu, guru juga mengeluh bila menemukan siswa yang kurang aktif di dalam proses pembelajaran, seperti kurangnya minat bertanya, sehinga guru berusaha untuk membuat siswanya tersebut menjadi aktif.

c. Media juga menjadi dalam pendekatan saintifik, sebab pemerintah tidak menyiapkan media sehingga guru harus membuat medianya sendiri. Dalam hal media tidak semuanya bisa dibawa kedalam kelas seperti gunung, hutan, dan lain-lain. Guru dalam mensiasati hal seperti itu, guru melakukan tamasya ke tempat-tempat seperti yang dipelajarinya. Guru Untuk membawa siswa ketempat tersebut membutuhkan biaya yang lumayan besar, ini juga yang menjadi kendala dalam hal implemntasi pendekatan saintifik.

A. Saran-saran

Berdasarakan kesimpulan tersebut di atas, maka saran-saran berikut dapat dijadikan pertimbangan sebagai bentuk optimalisasi pembelajaran menggunakan pendekatan saintifik pada pembelajara IPA:

1. Sekolah /madrasah

Sekolah yang maju adalah sekolah yang mau mengikuti perkembangan dunia pendidikan, untuk itu SD Muhammadiyah perlu meningkatkan pembelajaranya baik itu dari guru yang lebih profesional agar pendidikanya menjadi lebih baik.

2. Guru

a. Guru yang baik adalah guru yang mau menerima perubahan, melakukan pertumbuhan, dan perkembangan dalam dunia pendidikan, untuk itu guru perlu sekali merubah gaya dan bentuk mengajarnya, karena pendekatan dalam belajar itu tidak hanya satu akan tetapi banyak dan juga diharapkan selau melakukan trobosan-trobosan dalam bentuk gaya-gaya mengajar yang baru.

b. Guru dalam mengajar sebaiknya diikuti dengan media pembelajaran yang dapat dilihat, karena dengan media siswa menjadi lebih tertantang dan tertarik dalam proses pembelajaran.

3. Siswa

a. Peserta didik hendaknya lebih aktif dari yang sebelumnya agar proses pembelajaranya menjadi lebih baik.

b. Peserta didik sebaiknya lebih banyak membaca baik dari koran atau dari buku-buku yang lain yang terkait dengan pembelajaran yang dipelajari di kelas dengan tujuan agar ilmu atau wawasanya menjadi lebih banyak. 


\section{DAFTAR PUSTAKA}

Abdul Majid, Pembelajaran Tematik Terpadu, Bandung; Remaja Rosdakarya, 2014.

Abdul Majid \& Chaerul Rochman, Pendekatan Ilmiah Dalam Implementasi Kurikulum 2013 ,Bandung: PT Remaja Rosdakarya, 2014.

Abuddin Nata, Pemikiran Pendidikan Islam \& Barat, Jakarta, PT Raja Grapindo Persada: 2013.

Agus Wasisto Dwi Doso Warso, Pola Penjaminan Mutu Proses Pembelajaran IPA Di Madrasah Ibtidaiyah Kabupaten Klaten Jawa Tengah, Disertasi: UIN Sunan Kalijaga, 2012.

Amiruddin Hatibe, Ilmu Alamiah Dasar, Yogyakarta: Suka-Press UIN Sunan Kalijaga, 2012.

Anas Sudijono, Pengantar Evaluasi Pendidikan, Jakarta: Raja Grafindo Persada, 2005.

Cucun Novianti, The Power Of Success, Dinamika media, 2011.

Darmaningtiyas, Makalah Dalam Seminar Pendidikan dengan Tema "Kurikulum 2013: Persepektif Ideology, Filosofi, Dan Politik Pendidikan Nasional” yang Diselenggarakan oleh DEMA-F Ilmu Tarbiyah dan Keguruan UIN Sunan Kalijaga, di Gedung Convention Hall Lantai Dasar, Pada Hari Senin Tanggal 12 Mei 2014 Pukul 08:00 Sampai Jam 11: 30.

Dariyanto, Badrus Samsul Fata, Abi, John Rinaldi, Yogyakarta: Pustaka Pelajar, 2009.

Imam Suprayogo, Tobroni, Metodologi Penelitian Sosial-Agama, Bandung: Remaja Rosdakarya, Cet. Ke 2, Oktober 2003.

Indah Kosmiah, Belajar Dan Pembelajaran, Yogyakarta: Teras, 2012.

Juhaya S. Praja, Filsafat dan Metodologi Ilmu dalam Islam, Jakarta Selatan: Teraju, 2002.

Kementrian Pendidikan dan Kebudayaan Tahun 2013. Konsep Pendekatan Scientific.Diklat Dalam Rangka Implementasi Kurikulum 2013 
M. Hosnan, Pendekatan Sceintifik dan Kontekstual dalam Pembelajaran Abad 21, Bogor, Ghalia Indonesia: 2014

Mohammad Ali, Strategi Penelitian Pendidikan, Bandung: Angkasa, 1992.

Moh. Arif, Konsep Dasar Pembelajaran Sains Di Sekolah Dasar/MI , Yogyakarta: IAIN Tulunggung Press, 2014.

Moh. Yamin dan Vivi Auliya, Meretas Pendidikan Toleransi, Malang: Madani Media, 2011.

Muhaimin, Dkk, Pengmbangan (KTSP) Pada Sekolah \& Madrasah, Jakarta: PT Raja Grafindo Persada, 2008.

Muhammad Zaini, Pengembangan Kurikulum, Yogyakarta: Teras, 2009.

Mulyasa, E. Menjadi Kepala Sekolah Professional dalam Konteks Penyuksesan MBS Dan KBK, Bandung: Remaja Rosdakarya, 2005.

M. Lazim, Penerapan Pendekatan Saintifik dalam Pembelajaran Kurikulum 2013

-------------Pengembangan dan Implementasi Kurikulum 2013, Bandung: Remaja Rosdakarya, 2013.

Noeng Muhadjir, Metode Penelitian Kualitatif, Edisi IV, Yogyakarta: Rake Sasaran, 2000.

Norman K. Denzin Dan Yvonna S. Lincoln, Handbook Of Qualitative Research, Alih Bahasa Dariyanto, Badrus Samsul Fata, Abi, John Rinaldi, Yogyakarta: Pustaka Pelajar, 2009.

Nova ArdyWiyani, Pendidikan Karakter Berbasis Iman dan Taqwa, Yogyakarta: Teras, 2012.

Nurin Sapil, Penerapan Kurikulum Berbasis Kompetensi di Raudhatul Athfa (RA) UIN SunanKalijaga, Tesis: UIN SunanKalijaga, 2010.

Rahmat Raharjo, Pengembangan \& Inovasi Kurikulum, Yogyakarta: Baituna Publishing, 2012

Ridwan Abdullah Sani, Pembelajaran Saintifik untuk Implementasi Kurikulum2013, Jakarta: Bumi Aksara, 2014. 
Ridwan Husain, Implementasi Kurikulum Tingkat Satuan Pendidikan (KTSP) di MAN Sanana Kabupaten Kepulauan Sula Maluku Utara, Skripsi: UIN Sunan Kalijaga, 2009.

Rusman, Manajemen Kurikulum, Jakarta: PT Raja Grapindo Persada, 2009.

Setiawan Rizema Putra, Desain Belajar Mengajar Kreatif Berbasis Sains, Yogyakarta: Diva Press, 2013.

Sholehah Hidayat, Pengembangan Kurikulum Baru, Bandung: PT Remaja Rosdakarya, 2013.

Siti Fatonah \& Zuhdan K. Prasetyo, Pembelajaran Sains, Yogyakarta, Ombak: 2014.

Sri Minarti, Manajemen Sekolah, Yogyakarta: AR-RUZZ MEDIA, 2011.

Sugiyono, Metode Penelitian Kuantitatif, Kualitatif dan $R \& D$, Bandung: Alfabeta, 2013.

Sugiyono, Metode Penelitian Pendidikan Pendekatan Kuantitatif, Kualitatif, Dan $R \& D$, Bandung: Alfabeta, 2013.

Sumaji, Pendidikan Sains Yang Humanis, Yogyakarta: kanisius, 1998.

Suparlan Suhartono, Filsafat Pendidikan, Jogjakarta: AR-RUZZ MEDIA, 2009.

Suyanto dan Hariyanto, Belajar Dan Pembelajar, Bandung: PT Remaja Rosdakarya, 2012

Usman Samatowa, Pembelajaran IPA di Sekolah Dasar, Jakarta: PT Indeks, 2011.

WinaSanjaya, Kurikulum Dan Pembelajaran, Jakarta: Prenada Media Group, 2010.

Zainal Arufin, Konsep dan Model Pengembangan Kurikulum, Bandung: PT Remaja Rosdakarya, 2011.

http: sdmuhdemangan.blogspot.com/p/sejarah.html. diakses minggu 1 januari 2015 pukul 21:1 